\title{
VALORISATION OF FOREST AND AGRICULTURAL BIOMASS FOR THE SPANISH CERAMIC TILE INDUSTRY
}

\author{
David ALFONSO, Institute for Energy Engineering, Edificio 8E, Cubo F, Planta 5a , 46022 Valencia, Spain, daalso@iie.upv.es \\ Ana MEZQUITA, Institute of Ceramic Technology, Campus Universitari Riu Sec, 12006, Castellón, Spain, ana.mezquita@itc.uji.es \\ Eliseo MONFORT, Department of Chemical Engineering, University Jaume I of Castellón, Campus Universitari Riu Sec, 12006, \\ Castellón, Spain, eliseo.monfort@itc.uji.es \\ Daniel GABALDÓN-ESTEVAN, Department of Sociology and Social Anthropology, University of Valencia, pAv. Tarongers 4-b, \\ CP: 46021, Valencia, Spain, daniel.gabaldon@uv.es (corresponding author)
}

\begin{abstract}
Since ceramic tile industry is an energy intensive industry, European ceramic companies are challenged to reduce their $\mathrm{CO} 2 \mathrm{emissions}$ in the medium and long-term. According the Roadmap for moving to a low-carbon economy in 2050 (European Commission, 2011) the objective is to achieve a reduction in $\mathrm{CO}_{2}$ emissions of between $34 \%$ and $40 \%$ by 2030 , and between $83 \%$ and $87 \%$ by 2050 .

In the present paper we present a study on the viability of the incorporation of biofuels in the energy mix of the Spanish ceramic industry with the objective of (1) identifying the potential use of biomass resources, with a special focus of forest and agricultural biomass, in the manufacturing process of ceramic tile products; (2) identify in what part of the production process it can be introduced; and (3) calculate the reduced environmental impact from the manufacture of ceramic materials through a reduction in carbon dioxide emissions.

In order to proceed we firstly present the relevant state of the art for the study of the use of biomass for the ceramic manufacturing process. We continue with the methodology for biomass resources evaluation and present relevant data on forest and agricultural biomass for the ceramic tile industry. We then present data on the evolution and actual energy demand of the ceramic tile industry to characterize its energy demand. And then we identify an opportunity for biomass use in a specific phase of the manufacture of ceramic products, estimating the savings of fossil fuels and the reduction of carbon dioxide emissions and therefore assessing the environmental impact reduction through the introduction of biomass in the manufacturing process of ceramic tile products.
\end{abstract}

Keywords: biomass, ceramic tile industry, energy mix, energy transition, innovation system, sustainability, tiles

\section{INTRODUCTION}

There is a growing concern on the unsustainability of the actual production model of the so called developed countries, even more facing the rapid growth of other economies, and especially of those of Brazil, Russia, India and China (the BRIC countries), the consequent increase on the demand of energy and raw materials to feed that growth, and the diminishing capacity of the environment to assimilate, in a non-traumatic way, all that impacts of that economic activity. In mature industries, past success has often rested partially on comparative advantages such as pioneering activity, protected markets or, as in the case of the Spanish tile industry, because of favourable environmental regulation, raw material, transport and labour cost differentials (Gabaldón-Estevan \& Hekkert, 2013). With globalisation and the entry of new producers some of those earlier comparative advantages have become comparative disadvantages, as newcomers are operating under less restrictive legislation and lower costs. The challenge for mature districts increasingly depends in their ability to upgrade and innovate to avoid "getting locked into a race to the bottom" (Schmitz, 2004). An example of it is the Spanish ceramic tile industry where, during the early phases of its development, legislation was favourable compared to competitors from Italy in terms of employment and environmental issues. However, Spain's membership of what was the European Economic Community, now European Union, has progressively reduced these differences to the point that competition currently comes from new entrants from China, Brazil, Mexico, etc. and is similar to that faced by the Italian tile industry. Consequently there is a need for mature industries to be innovative in order to face these challenges.

According to Gabaldón-Estevan et al. (2014b) at the EU the manufacturing subsectors with lower productivity and exposed to an international market are more vulnerable to the increasing pressure on environmental regulations as they have to confront competitors playing in the same field but at non-EU countries. This in turn is provoking a debate over the sustainability of the so-called traditional industries in the EU due to increased public awareness of the diminishing capacity of the environment to assimilate the impacts of human activity and increased demand for environmental sustainability. The analysis of environmental innovations, understood as "all the changes in the product portfolio or in the production processes that tackle sustainability targets, like waste management, eco-efficiency, emissions reduction,

Copyright (C) 2015 The Authors. Published by Aleksandras Stulginskis University. This is an open-access article distributed under the terms of the Creative Commons Attribution License (CC-BY 4.0), which permits unrestricted use, distribution, and reproduction in any medium, provided the original author and source are credited. 
recycling, eco-design or any other action implemented by firms to reduce their environmental footprint" (De Marchi, 2012: 615), is a growing research area in both the social and natural sciences (Markard et al., 2012).

As a consequence there is a growing awareness of the environmental challenges facing the ceramic tile industry in the coming years, especially those related to energy and emissions (Monfort et al., 2014), and the potential of its innovation system, through environmental innovation, to generate and adapt technologies and improve production techniques

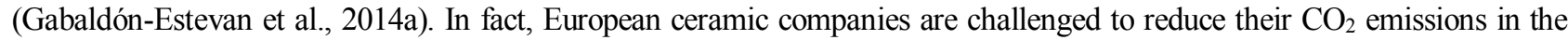
medium and long-term as signalled by the Roadmap for moving to a low-carbon economy in 2050 (European Commission, 2011). This document provides objectives for reducing $\mathrm{CO} 2$ emissions in all industrial sectors including ceramics. The objective is to achieve a reduction in $\mathrm{CO}_{2}$ emissions of between $34 \%$ and $40 \%$ by 2030, and between $83 \%$ and $87 \%$ by 2050 .

This paper* attempts to help bypassing the obstacles of the ceramic tile industry look-in by assessing the opportunity of a biofuel niche development. For this we continue with the methodology for biomass resources evaluation and present relevant data on forest and agricultural biomass for the ceramic tile industry. We then present data on the evolution and actual energy demand of the ceramic tile industry and characterize its energy demand. We then we identify the opportunity for biomass use in a specific phase of the manufacture of ceramic products and estimate the savings of fossil fuels and the reduction of carbon dioxide emissions in order to assess the environmental impact reduction through the introduction of biomass in the manufacturing process of ceramic tile products.

\section{METHODOLOGY FOR BIOMASS RESOURCES EVALUATION}

Methodologically it can be analysed wide geographic areas by making subdivision and considering a potential biomass plant in each subdivision. Subdivision size can obey to administrative boundaries (default option), customer defined groups of municipalities or other specific criteria (i.e. upper limit for transport distance).

Biomass sources considered in this analysis are those derived from forestry, agricultural crops (woody crops as olives, grapes, oranges, almonds, apples, etc.; and herbaceous crops such as rice, wheat, barley, maize) and agro-industries (olive oil industries, wine production industries, dry fruits peeling plants, rice mills, and the like). For this research, quantification of biomass resources is performed using generation ratios as those described in Table 1. These generation ratios and characterization of produced waste biomass (higher heating value, moisture and ash content) have been obtained from existing bibliography (Di Blasi et al, 1997; Dias \& Azevedo, 2002; Voivontas et al, 2001; EUBIONET, 2002, 2003; ECN, 2014) and from direct analysis performed during both BIOVAL ${ }^{\dagger}$ and ESTIBMEIC $\ddagger$ projects.

Table 1. Biomass resources quantification. Generation ratios for agricultural residues.

\begin{tabular}{|c|c|c|c|c|c|c|}
\hline Code & $\begin{array}{c}\text { Biomass } \\
\text { resource } \\
\text { (type of crop) }\end{array}$ & Description & $\begin{array}{l}\text { Waste biomass } \\
\text { generation ratio } \\
\text { (referred to wet } \\
\text { biomass) }\end{array}$ & $\begin{array}{c}\text { HHV } \\
\left(\mathrm{MJ} \cdot \mathrm{kg}^{-1} \text { dry }\right)\end{array}$ & $\begin{array}{l}\text { Moisture } \\
(\% \text { wet basis, } \\
\text { fresh })\end{array}$ & $\begin{array}{c}\text { Ash } \\
\text { (\%dry basis) }\end{array}$ \\
\hline $\mathrm{AG}_{\mathrm{Ai}}$ & $\begin{array}{l}\text { Agricultural } \\
\text { residues from } \\
\text { woody crops }\end{array}$ & $\begin{array}{l}\text { Annual tree } \\
\text { prunings }\end{array}$ & $\begin{array}{l}1.8-4.1\left(\mathrm{t} \cdot \mathrm{year}^{-1} \cdot \mathrm{hm}^{-2}\right. \\
\text { of cropland })\end{array}$ & $17.2-18.4$ & $30-40 \%$ & $1.8-3.4 \%$ \\
\hline $\mathrm{AG}_{\mathrm{Bi}}$ & $\begin{array}{l}\text { Agricultural } \\
\text { residues from } \\
\text { herbaceous crops }\end{array}$ & $\begin{array}{l}\text { Cereal straw, } \\
\text { maize cobs and } \\
\text { stalks }\end{array}$ & $\begin{array}{l}1.5-7.8\left(\mathrm{t} \cdot \text { year }^{-1} \mathrm{hm}^{-2}\right. \\
\text { of cropland })\end{array}$ & $16.8-18.1$ & $20-30 \%^{\mathrm{a}}$ & $4.2-7.5 \% \mathrm{~b}$ \\
\hline $\mathrm{FR}_{\mathrm{i}}$ & Forestry residues & $\begin{array}{l}\text { Silviculture } \\
\text { waste }\end{array}$ & $\begin{array}{c}1.0-1.9\left(\mathrm{t} \cdot y^{-} \mathrm{rea}^{-1} \cdot \mathrm{hm}^{-2}\right. \\
\text { of woodland })\end{array}$ & $18-20 \%$ & $29-45 \%$ & $1.2-3.4 \%$ \\
\hline $\mathrm{AI}_{\mathrm{i}}$ & $\begin{array}{l}\text { Agro-industrial } \\
\text { residues }\end{array}$ & $\begin{array}{l}\text { Fruit peels and } \\
\text { pulp, cereal } \\
\text { husk, dry fruit } \\
\text { shells }\end{array}$ & $\begin{array}{l}0.16-3.6\left(\mathrm{t} \cdot \mathrm{t}^{-1} \text { of }\right. \\
\text { product })\end{array}$ & $16-22.0 \%$ & $50-65 \%{ }^{\mathrm{c}}$ & $2-6 \%{ }^{\mathrm{d}}$ \\
\hline
\end{tabular}

The methodology includes the analysis of availability, for energy use in industries or power plants, of each type of agricultural and forestry waste biomass (availability coefficients), defined according to bibliography (Voivontas et al, 2001; EUBIONET, 2003) and additional surveys performed by the authors, being important to take into account other uses of biomass (i.e. animal feeding, domestic fuel), and size of agricultural plots. In Table 2 it has been included a summary of availability considerations. For agricultural waste biomass global availability was in the range $20-40 \%$ referred to the total theoretical biomass production.

\footnotetext{
* ACKNOWLEDGMENTS

This work was supported by the project ESTIBMEIC- GV/2014/049 (Generalitat Valenciana)

'BIOVAL is a project titled "Optimization of the Energy Use of Biomass Resources in the Valencian Region", 2005 - 2006, funded by the regional government of the Valencian region - IMPIVA, Generalitat Valenciana- and the European Fund of Regional Development)

${ }^{\ddagger}$ ESTIBMEIC stands from Socio-Technical Study on the Incorporation of Biofuels in the Energy Mix Ceramic Industry (project name in Spanish)
} 
Table 2. Biomass resources availability for energy use.

\begin{tabular}{lcl}
\hline $\begin{array}{l}\text { Biomass } \\
\text { resource }\end{array}$ & $\begin{array}{l}\text { Availability for energy } \\
\text { use }\end{array}$ & Additional considerations \\
\hline $\begin{array}{l}\text { Tree prunings } \\
\left(\mathrm{AG} \mathrm{Ai}_{\mathrm{i}}\right.\end{array}$ & $60-80 \%$ & $\begin{array}{l}\text { It was considered that biomass from plots smaller than a minimum value }(0.6-0.8 \\
\left.\mathrm{hm}^{2}\right) \text { would not be collected due to difficult accessibility and logistics (for the same } \\
\text { total area, many small plots instead of few big ones provide higher management } \\
\text { complexity) }\end{array}$ \\
$\begin{array}{l}\text { Cereal straw \& } \\
\text { similar }\left(\mathrm{AG}_{\mathrm{Bi}}\right)\end{array}$ & $\begin{array}{l}15-30 \% \text { (rice straw \& } \\
\text { corn stalks } 50-60 \%)\end{array}$ & $\begin{array}{l}\text { This percentage represents the waste biomass produced due to silviculture treatments } \\
\text { really performed in Spain compared with the theoretical potential value computed } \\
\text { according to woodland surface. }\end{array}$ \\
$\begin{array}{l}\text { Forestry } \\
(\mathrm{FR})\end{array}$ & $20-40 \%$ &
\end{tabular}

The Spanish tile industry, which includes production of ceramic floor and wall tiles, decorative pieces, frit and glaze, machinery and equipment as well as other activities related to the ceramic process, has adopted an industrial district agglomeration (Gabaldón-Estevan et al., 2012) and is located in Castellon province, in the north of the Valencia region (Figure 1). More than $90 \%$ of both Spanish tile companies and Spanish tile production is concentrated in the Castellon province in a small area of about 20 kilometre radius.

Geographic location of biomass residues can be performed using GIS with a resolution of $1-\mathrm{km}^{2}$ pixel or using municipalities as minimum area units, Figure 1 shows the biomass resources evaluation results (including availability considerations) per municipality as biomass density according to total municipality area.

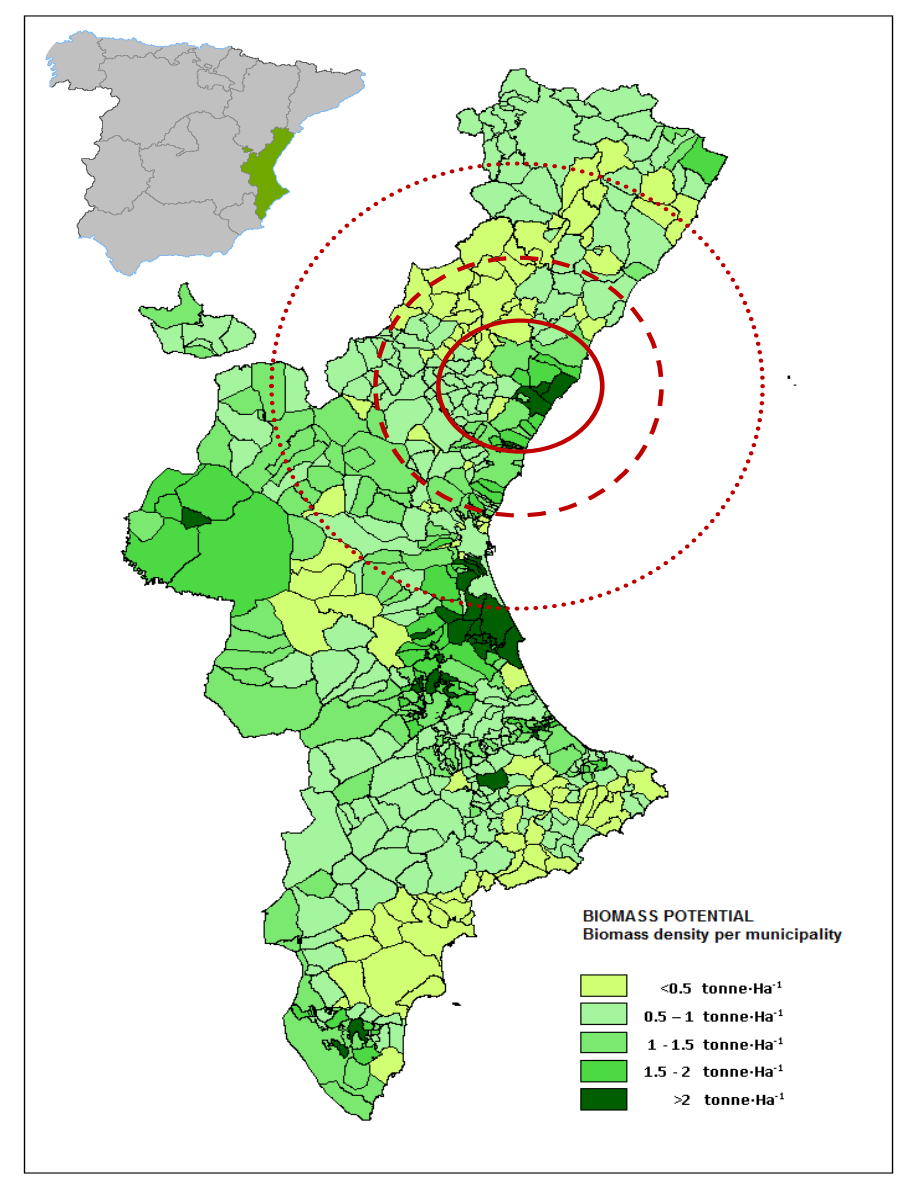

Figure 1. biomass potential around Castellon area (Source: own elaboration)

\section{EVOLUTION AND ACTUAL ENERGY DEMAND OF THE CERAMIC TILE INDUSTRY}

Tile industry consumes considerable amounts of energy along its value chain. Starting from mining activities, the transport of those materials to the processing plants, the processing of those materials to make them ready for the tile production, the tile production itself and the storage and the delivery of those tiles once packed. Last century tile industry made two radical energy transitions: from traditional biomass to hydrocarbon resources, first to fuel and then to natural gas (Figure 2). And 
although nowadays fuel and electricity are also consumed in the sector, the main energy source consumed is natural gas.

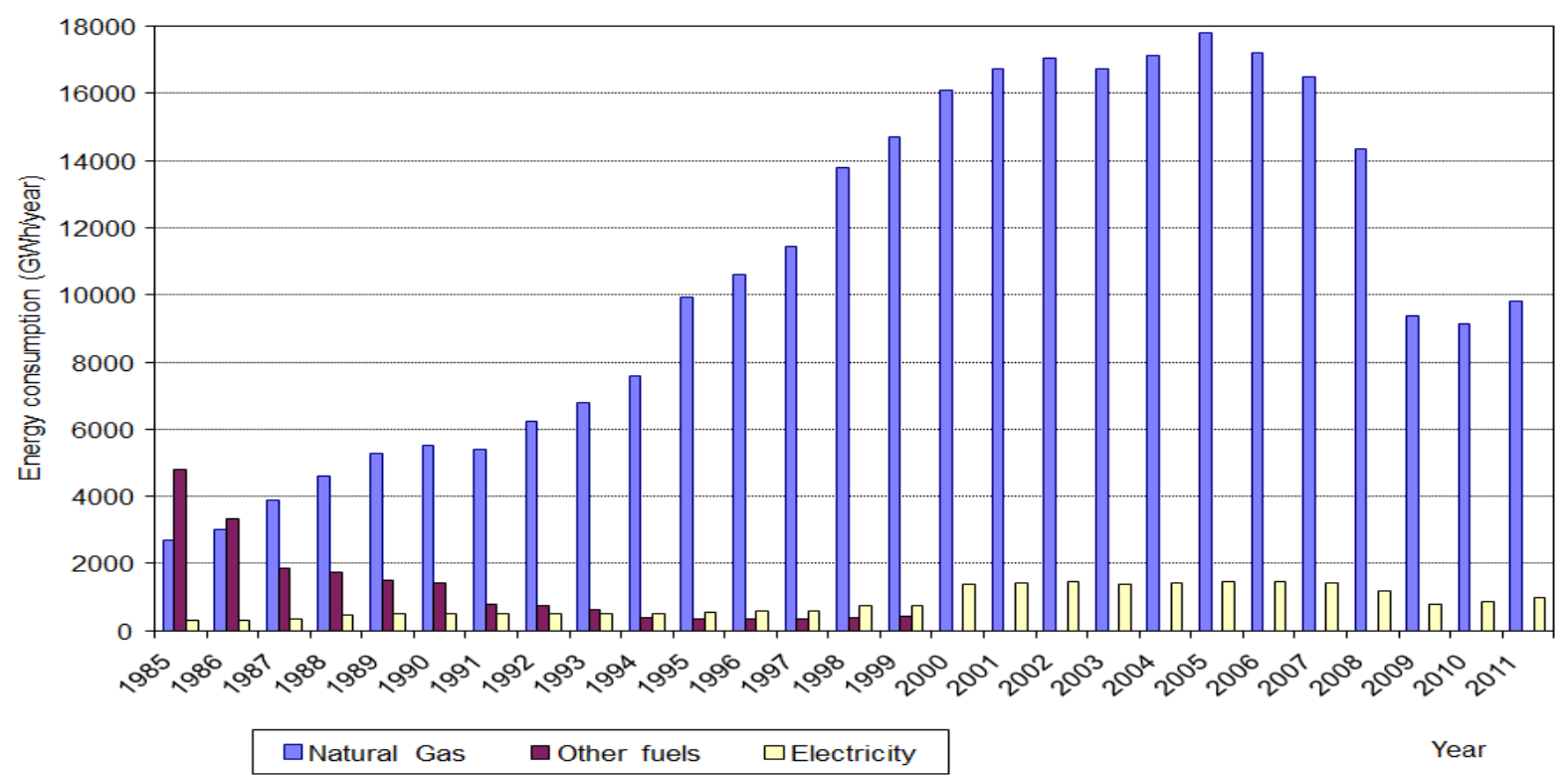

Figure 2: Energy mix and consumption in the Spanish ceramic tile industry (GWh/year), 1985-2011 (Source: Monfort et al. 2014)

Gas feeds the most energy consuming facilities within the ceramic manufacturing process, this is to say, the spray dryers (dryers for ceramic slurry) that represents $36 \%$ of thermal energy consumption. The driers (dryers of the green bodies of the tiles), that represents $9 \%$ of thermal energy consumption. And the kilns, where final product is fired representing the $55 \%$ remaining thermal energy consumption. Electricity is consumed in all other activities of the ceramic processing.

Most spray dryers have installed a cogeneration system, which consists of a gas turbine, where both thermal energy and electricity are produced simultaneously. The thermal energy is contained in the combustion gases of the gas turbine, that are used in the spray drying process as drying gases. The electricity produced can be consumed in the process or send to the electricity grid, depending on the choice of the company. The global efficiency of this system (cogeneration + spray dryer) is $85-90 \%$, which has led in a reduction of carbon dioxide $\left(\mathrm{CO}_{2}\right)$ and nitrogen dioxide $\left(\mathrm{NO}_{2}\right)$, comparing with the initial situation, which was a power central station to produce electricity and a burner fuelled by natural gas for producing hot gases for the spray dryer.

In general, the technology of the manufacturing ceramic process is a mature technology. Although measurements to assess efficiency in real plants are difficult to obtain an optimal efficiency, according to representatives of the industry, with the technologies available, has nearly been achieved, due to the fact that in general the ceramic sector is using Best Available Techniques. Some activities are being implemented to further reduce energy consumption, such as combustion air pre-heating, energy recovery from kilns to dryers or spray dryers, improvements in burners design, etc., but important further $\mathrm{CO}_{2}$ emissions reduction should only be achieved by incorporating new technologies. In fact, $\mathrm{CO}_{2}$ emissions trends have been similar (Figure 3) since most $\mathrm{CO}_{2}$ emissions are due to the combustion process (90\%). The remaining $10 \%$ is due to the decomposition of the carbonates used for the body composition of earthenware (wall) tiles. Hence the floor/wall tile production ratio has a minor effect on total $\mathrm{CO}_{2}$ emissions.

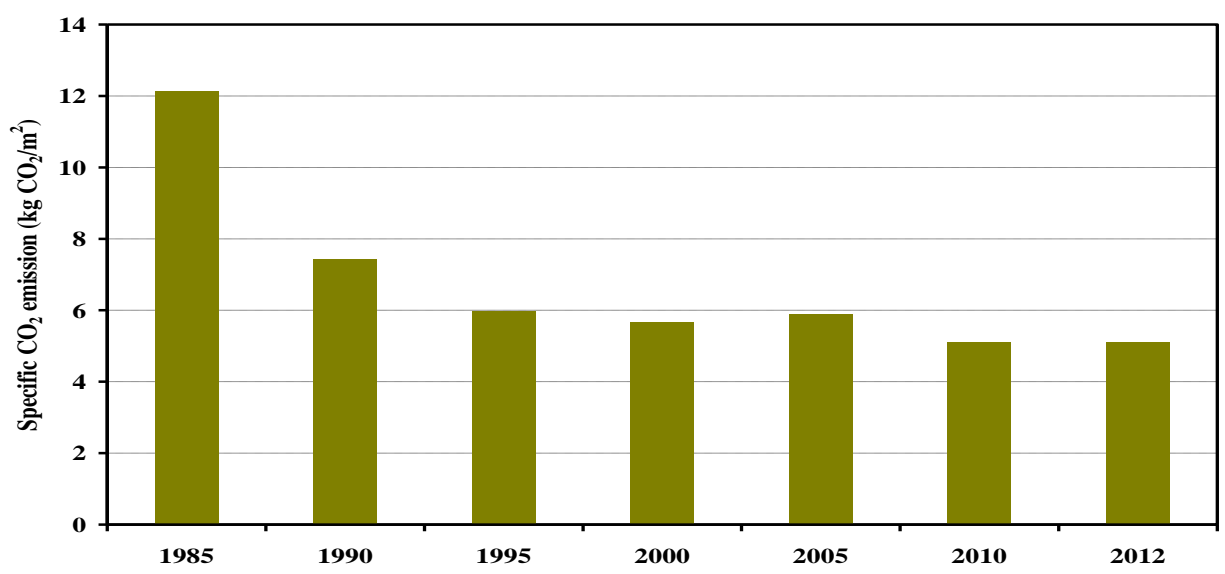

Figure 3. Evolution of the specific CO2 emission in the Spanish ceramic tile industry, 1985-2012 (Source: Gabaldón-Estevan et al. 2014b)

European and national climate policies are pushing the ceramic industry to look for new technologies applicable to their processes that have less environmental impact. Among others, the emerging new sources of agricultural biomass open the possibility for path-making in the energy system in the Spanish Tile Sector. 


\section{ENVIRONMENTAL IMPACT REDUCTION THROUGH THE INTRODUCTION OF BIOMASS IN THE MANUFACTURING PROCESS OF CERAMIC TILE PRODUCTS}

Within the various possibilities, such as agricultural residues; dedicated energy crops; forestry; industry; parks and gardens; waste; or other (such as roadside hay, husks/shells), for this work we focus on forestry and agricultural residues. Parent et al. (2014) point that the global transition from fossil fuel-based energy sources to renewable energy sources will be most effective, for at least the near future, by utilizing local resources and existing infrastructure.

As we have mentioned above, within the manufacturing process firing and drying are the environmental hot spots. Biomass could be used on drying process (with indirect heat exchanger) with oil boiler. In words of the European Ceramic Industry:

"For high-temperature firing, the most promising way to reduce fuel emissions is to replace natural gas by biogas or syngas from biomass or waste, modifying existing kilns through retrofitting. Syngas produced by the gasification of organic waste or biomass also has a higher potential to replace natural gas and significantly reduce emissions, particularly in the brick and roof tile sectors. On average, the kiln represents $80 \%$ of the natural gas consumption of a clay production unit. Substitution rates of up to $80 \%$ syngas could technically be possible in some plants, with a potential reduction of running costs. This could reduce $\mathrm{CO}_{2}$ emissions by over $30 \%$ \%" (Cerame-Unie 2012: 13)

The major factors influencing design of equipment are (1) the fuel properties (e.g. bulk density, moisture, proximate and ultimate analysis, calorific value, ash properties, and size characteristics); (2) the thermal requirement (e.g. heat load, processing temperature, furnace and heat exchanger design, etc.); (3) the economics (e.g. cost of available fuels, labour rates, equipment costs); (4) the local factors (e.g. operational and construction/maintenance skills, spares availability, roads and local infrastructure, environmental legislation); and (5) the fuel handling.

Also, the selection of suitable handling equipment for biomass fuels is important. Biomass fuel quality is very variable in terms of moisture content, shape and size, and contamination. Flow properties are strongly influenced by such quality variations. Use of hoppers for particulate biomass storage is greatly dependent upon having effective discharge equipment. Common devices are stirring screws, rotary screw conveyors, travelling screw conveyors and en-mass bottom grid conveyors. Such systems are expensive, so storage in piles is common.

Moving biomass fuel mechanically, as in automatic feeding into furnaces, will usually require either pneumatic, screw or trough type conveyors - with choice depending on the particular properties of the fuel.

Thermal oils or heat transfer fluids are widely used to carry thermal energy in process heating, metal working and machine cooling applications. They are mainly used in high temperature process applications where the optimum bulk fluid operating temperatures of between $150^{\circ} \mathrm{C}$ and $400{ }^{\circ} \mathrm{C}$ are safer and more efficient than steam, electrical, or direct fire heating methods.

According to BIOVAL (Ref. MAC/3/C216) project, biomass transport cost (including first transformation), is about $60 € / \mathrm{t}$. The biomass available in the province of Castellón is mainly of forest origin ( $60 \%$ of the area of the province is forest land) and there is great potential for biomass from woody crops (mainly citrus, olive and almond trees). At the provincial level forest residual biomass is estimated at 40,000 tons and about 150,000 tons agricultural waste. It should be noted that the properties of the biomass as fuel are suitable for use energy, and its calorific value, dry, of 17.5-19.9 $\mathrm{MJ} / \mathrm{kg}$ and ash percentages of $1-3 \%$ (dry basis).

At Valencia regional level biomass properties are similar except for rice areas under irrigation and rain fed cereal (for these areas the calorific value drops by $8-12 \%$, and the percentage of ash can reach up to $18 \%$ (e.g. rice straw). The representative price of forest-based chips (the most commercially available) is in the range $45-55 € / t$ ( $25 \%$ moisture approx.).

The drying process fuel consumption is of about 3 to $3.9 \mathrm{kWh} / \mathrm{m}^{2}$ depending on type of tile (Monfort et al. 2010), as 1 tone of fresh biomass has about 2,980 $\mathrm{kWh}$, thus each tonne could cover drying fuel need equivalent to 764 up to $993.3 \mathrm{~m}^{2}$ of tiles. Therefore net $\mathrm{CO}_{2}$ savings, taking into account biomass transport and conditioning, could be about 0.5 to $0.6 \mathrm{~kg} \mathrm{CO}_{2}$ per $\mathrm{m}^{2}$.

\section{CONCLUSIONS}

In the present paper we have presented a study on the viability of the incorporation of biofuels in the energy mix of the Spanish ceramic industry with three objectives: Firstly to identify the potential use of biomass resources, with a special focus of forest and agricultural biomass, in the manufacturing process of ceramic tile products, for that we have shown a methodology for biomass resources evaluation and present relevant data on forest and agricultural biomass for the ceramic tile industry in the Castellon province. Secondly we have identified that the part of the manufacture of ceramic products where it can be more easily introduced is in the drying phase of the production process, as we have also shown, the driers of the green bodies of the tiles consumption representing $9 \%$ of actual thermal energy consumption. And thirdly, we have assessed the reduced environmental impact from the manufacture of ceramic materials through a reduction in carbon dioxide emissions of about 0.5 to $0.6 \mathrm{~kg} \mathrm{CO}_{2}$ per $\mathrm{m}^{2}$, taking into account biomass transport and conditioning.

However, technical, economic and social analysis of each identified opportunity has to be further studied for obtaining a better picture of the challenges to boost the sustainable use of biomass for energy in the production processes of the ceramic industry.

\section{REFERENCES}

1. Cerame-Unie. 2012 Paving the way to 2050: the Ceramic Industry Roadmap. Available at: 
http://cerameunie.eu/en/doc/197/CU\%20Ceramic\%20Roadmap\%202p.pdf_[accessed on 06/06/2015]

2. De Marchi, V. 2012 Environmental innovation and R\&D cooperation: Empirical evidence from Spanish manufacturing firms, Research Policy, Vol. 41, Iss. 3, 614-623 http://dx.doi.org/10.1016/j.respol.2011.10.002

3. Di Blasi, C., Tanzi, V., Lanzetta, M. 1997. A study on the production of agricultural residues in Italy. Biomass and Bioenergy, Vol. 12, Iss. 5, pp. 321-331. http://dx.doi.org/10.1016/S0961-9534(96)00073-6

4. Dias, J., Azevedo J. L.T . 2002. Evaluation of biomass residual in Portugal mainland. Proceedings of the Conference on New and Renewable Energy Technologies for Sustainable Development, Ponta Delgada, Azores, Portugal, pp. 215-228. Available at: http://altercexa.eu/images/archivos/Areas\%20Tematicas/Biomasa/artigo_biomassa.pdf

5. ECN. Phyllis - the composition of biomass and waste. http://www.ecn.nl/phyllis/ (accessed 06/10/14).

6. EUBIONET. 2003. Biomass survey in Europe. Country report of Greece European Bioenergy Network. European Energy Exchange. Available at: http://www.eubionet.net/ (accessed 05/09/14).

7. EUBIONET. 2002. Biomass survey in Europe. Country report of Spain-Andalusia. European Bioenergy Network. European Energy Exchange. Available at: http://www.eubionet.net/ (accessed 06/10/14).

8. European Commission. 2011. A Roadmap for moving to a competitive low carbon economy in 2050.

9. Gabaldón-Estevan, D., Criado, E., Monfort, E. 2014a. The Green Factor in European Manufac-turing: A case study of the Spanish ceramic tile industry. Journal of Cleaner Production, Vol. 70, pp. 242-250 http://dx.doi.org/10.1016/j.jclepro.2014.02.018

10. Gabaldón-Estevan, D.; Fernández de Lucio, I. Molina Morales, F. X. 2012. Distritual Innovation Systems. ARBOR-Ciencia pensamiento y cultura, Vol. 188 (753), pp. 63-73 http://arbor.revistas.csic.es/index.php/arbor/article/download/1448/1457

11. Gabaldón-Estevan, D., Hekkert, M. P. 2013. How Does the Innovation System in the Spanish Tile Sector Function? Bol Soc Esp Ceram, Vol. 52, Iss. 3, pp. 151-158. Available at: http://boletines.secv.es/upload/20130704104006.201352151.pdf

12. Gabaldón-Estevan, D.; Mezquita, A.; Ferrer, S.; Monfort, E. 2014b Is European Union Environmental Policy Efficient at Promoting a Post-carbon Industry? The Case of Energy in the European Ceramic Tile Sector. Proceedings of the 11th ICIM 2014, Vaasa (Finland) 104-113 Available at: http://icim.vamk.fi/2014/uploads/UploadPaperDir/11thICIM2014.pdf

13. Markard, J., Raven, R., Truffer, B. 2012 Sustainability transitions: An emerging field of research and its prospects, Research Policy, Vol. 41, Iss. 6, pp. 955-967. http://dx.doi.org/10.1016/i.respol.2012.02.013

14. Monfort, E., Mezquita, A., Granel, R., Vaquer, E., Escrig, A., Miralles, A., Zaera, V. 2010. Analysis of energy consumption and carbon dioxide emissions in ceramic tile manufacture. Boletín de la Sociedad Española de Cerámica y Vidrio, Vol. 49, No. 4, pp. 303-310. Available at: http://boletines.secv.es/upload/20100901173134.201049303.pdf

15. Monfort, E., Mezquita, A., Vaquer, E., Mallol, G., Gabaldón-Estevan, D. 2014 La evolución energética del sector español de baldosas cerámicas. Boletín de la Sociedad Española de Cerámica y Vidrio, Vol. 53, No. 3, pp. 111-120 Available at: http://boletines.secv.es/upload/2014070792201.201453111.pdf

16. Parent, J., Graziano, M., Yang, X. S. 2014. Potential of using forest residue to offset coal use in co-fired coal power plants in the eastern United States. International Journal of Agricultural and Biological Engineering, Vol. 7, No. 4, pp. 99-105 Available at: https://ijabe.org/index.php/ijabe/article/view/1281

17. Schmitz, H. 2004. Globalized localities: introduction. In Schmitz, H. (Ed.) Local enterprises in the global economy: issues of governance and upgrading. Edward Elgar. Cheltenham, United Kingdom, pp. 1-19. http://dx.doi.org/10.4337/9781843769743.00008

18. Voivontas, D., Assimacopoulos, D., Koukios, E. G. 2001. Assessment of biomass potential for power production: a GIS based method. Biomass and Bioenergy, Vol. 20, Iss. 2, pp. 101-112. http://dx.doi.org/10.1016/S0961-9534(00)00070-2 